\title{
Commenting on Credibility in Kansas: A Constructive Criticism of State v. Pabst
}

\author{
Steve Leben ${ }^{*}$
}

In some respects, this is a cautionary tale about overruling precedent. The Kansas Supreme Court openly overruled its own thirty-two year old precedent in deciding State v. Pabst in 2000. ${ }^{1}$ Cautionary tales and precedents aside, this Article is primarily about how trials are conducted, and how much latitude an attorney should have in Kansas to talk directly to jurors in closing argument about all the issues-including witness credibility - that will decide the case. Pabst forced attorneys to change the way they conduct closing arguments. While the result in Pabst was right, the rationale the court used to support the decision was not. I hope to convince you in this Article that the court was wrong to overrule its precedent, and that the court should now acknowledge the error.

The Pabst court broadly held that attorneys may not talk about witness credibility during closing argument. That rule is unwise, unworkable, and unnecessary. It's unwise because trials usually come down to credibility issues, and fact-finders-usually juries-deserve to have our best effort in focusing on the real issues before them. It's unworkable because criminal defendants have a constitutional right to address credibility issues in closing argument, and a one-sided rule cannot work in an adversarial system of justice. And it's unnecessary because other methods are available to address prosecutorial misconduct that do not interfere with the ability to address the key issues in a trial.

\section{THE PABST OPINION OVERRULED PRECEDENT TO CONCLUDE THAT AN ATTORNEY MAY NOT COMMENT ON WITNESS CREDIBILITY IN Closing ARGUMENT}

Tod Alan Pabst shot his fiancée, Phoebe Harkins, twice in their home in March 1997. ${ }^{2}$ Pabst testified in his own defense. He claimed that

\footnotetext{
* Judge, Kansas Court of Appeals. B.S., 1978, journalism, University of Kansas; J.D., 1982, University of Kansas.

1. 996 P.2d 321 (Kan. 2000)

2. Id. at 324 .
} 
Harkins had reacted negatively to some good news he had given her and that this had "made him feel worthless." 3 He said he had retrieved a revolver from his truck and handed it to Harkins, telling her "to shoot him if she thought he was so worthless." "4 Pabst said that Harkins again reacted badly, saying that she might shoot herself or their three-year-old daughter. ${ }^{5}$ He said that they then struggled over the gun from a standing position and began to fall onto the couch when the gun went off. ${ }^{6} \mathrm{He}$ said that both of their hands were on the gun for at least the first shot. ${ }^{7}$

But the State's evidence contradicted Pabst's testimony. Police found Harkins in a sitting position on the couch, with her legs crossed and her torso slumped to the side. ${ }^{8}$ The blood-pattern evidence also indicated that Harkins was sitting upright on the couch when she was shot. ${ }^{9}$ Ballistic evidence also countered Pabst's story; an expert testified that the gun was at least one to five feet away from Harkins when it was fired. ${ }^{10}$ One of the bullets struck her in the head just behind her right ear and exited just behind her left ear. ${ }^{11}$ The other bullet passed through her arm, into her chest, through a lung, and into her spinal column. ${ }^{12}$ Either shot was sufficient to kill her. ${ }^{13}$

Law students given just those facts would be able to prepare a devastating cross-examination of Pabst. No doubt an experienced prosecutor was able to do so as well. According to the State's closing argument, the defendant responded, "I don't know," forty-two times during his testimony. ${ }^{14}$ Obviously, the key question for the jury to determine was whether there was any shred of truth in anything that the defendant said had occurred. The State's case seemed strong. But had the defendant's testimony raised reasonable doubt?

The prosecutor was Stephen Maxwell, who was then an assistant attorney general. ${ }^{15}$ His closing argument was self-righteous and
3. Id.
4. Id.
5. Id.
6. Id.
7. Id.
8. Id.
9. Id.
10. Id.
11. Id.
12. Id.
13. Id.
14. Id. at 325 .
15. Id. at 323 . 
hammered at Pabst as a liar. The Supreme Court set out a lengthy excerpt in its opinion:

"[PROSECUTOR]: ... During the Defendant's testimony you heard 42 'I don't knows.' You heard many lies that I think you heard. The Defendant [sat] right before you and lied to you about what happened....

$\cdots$

"While the defense attorney's talking to you, remember one thing; the State put the facts in front of you. We didn't lie to you. We didn't hide anything. We put all the facts in front of you for you to decide, because the State seeks justice here. They seek the proper result based on the evidence. And what did the Defendant do? He lied to you. Many, many times, he lied to you. So while Mr. Falk talks to you, remember that his client, the Defendant, lied to you. He didn't even give you close to a reasonable explanation. Ladies and gentlemen, listen to him with that in your mind.

$\cdots$

“... He wants you to have it both ways. Believe the Defendant's testimony, ladies and gentlemen, in order to buy defense counsel's argument here, you have to believe this Defendant. And you saw him. You heard from him. I look into each one of your eyes and I tell you he lied.

"[DEFENSE COUNSEL]: Objection. Inappropriate comment by counsel. Cannot interject personal feelings.

"THE COURT: Sustained. Ladies and gentlemen, I would again direct you to disregard the last comment of counsel.

"[DEFENSE COUNSEL]: Your Honor, to preserve the record, we'd move for a mistrial at this time based on prosecutorial misconduct.

"THE COURT: And that would be denied. Please continue, Mr. Maxwell.

"[PROSECUTOR]: The State tells you he lied. The State of Kansas-

"[DEFENSE COUNSEL]: Objection, Your Honor. It's inappropriate for him to make-

“[PROSECUTOR]: That's fair comment, Your Honor.

"THE COURT: Overruled. 
"[PROSECUTOR]: The State tells you he lied, ladies and gentlemen. He lied to you. He got on that witness stand and he lied directly to you. He got up, down here in front of you, and he again lied directly to you. He could not explain this. He had no explanation."

The court found that Maxwell had "accused Pabst of lying at least 11 times during closing argument."

When it decided Pabst, the court knew that its own precedents clearly allowed a prosecutor to comment about witness credibility during closing argument. Pabst cites-and overrules-State v. McClain, ${ }^{18}$ a 1975 decision explicitly holding that "counsel may comment on the credibility of a witness" so long as the remarks are "based on the facts in evidence." ${ }^{\prime 19}$ Like the prosecutor in Pabst, the prosecutor in McClain had attacked the defendant's credibility during closing argument, saying explicitly that the defendant had lied:

Why would this man get on the witness stand, if you find that he lied, and lie to you? And we submit that he has lied[;] logic tells you that he has lied.

Here is a man that has had four months, ladies and gentlemen, ... had the opportunity to concoct a story for you that squares with logic. ${ }^{20}$

The McClain court found that this argument did not violate rules prohibiting a prosecutor from stating a personal opinion about witness credibility. Instead, the court found that it was "no more than comment on the inherent improbability of the testimony given" by the defendant and was proper argument from the evidence presented. ${ }^{21}$

The Pabst court relied upon four authorities for its holding that the prosecutor acted improperly when he claimed the defendant had lied under oath. First, citing State v. Lockhart, ${ }^{22}$ the court held that "the assertion that Pabst lied was improper." ${ }^{23}$ In Lockhart, the prosecutor told the jury that both the defendant and his attorney had lied to the jury; the Court of Appeals concluded that "a fair reading of the transcript reveals nothing but ill will on the part of the prosecutor" in making his

16. Id. at $325-26$.

17. Id. at 325 .

18. 533 P.2d 1277 (Kan. 1975), overruled by State v. Pabst, 996 P.2d 321 (Kan. 2000).

19. Id. at 1282 .

20. Brief of Appellant at 14, McClain, 533 P.2d 1277 (Kan. 1975) (No. 47,551); Record on Appeal at 28, McClain, 533 P.2d 1277 (Kan. 1975) (No. 47,551).

21. McClain, 533 P.2d at 1282.

22. 947 P.2d 461, 465 (Kan. Ct. App. 1997).

23. State v. Pabst, 996 P.2d 321, 326 (Kan. 2000). 
argument. ${ }^{24}$ The Lockhart court said that "[t]rials cannot be allowed to degenerate into name-calling contests." 25

Second, the court held that it was improper for the prosecutor to say, "We didn't lie to you." ${ }^{26}$ Citing State v. Mosley, ${ }^{27}$ the Pabst court said that this was "an attempt to bolster the credibility of the State's witnesses" and found such bolstering improper. ${ }^{28}$ In Mosley, the prosecutor had said that "my witnesses were telling the truth," that it was the defendant "who's on trial," not the State's witnesses, that the defendant's "whole game ... is to confuse you," and that "I guarantee you ... if my witnesses would have come up here and had the exact same story, they would have yelled conspiracy." 29 The Kansas Court of Appeals had found these comments "perilously close [but] not so egregious as to require a reversal." 30

If the Pabst court had stopped there, its decision would have been in tune with Kansas precedents and fairly unremarkable. The prosecutor in Pabst, contrary to Lockhart, had turned the closing argument into a name-calling session and called the defendant a liar eleven times. People might disagree about whether that was over the top, but it was not a big surprise that a court found that it was. Maxwell also had improperly vouched for his witnesses in a personal way through his "We didn't lie to you" statement and discussion. The prohibition on lawyers vouching for their witnesses is also a well-known rule.

But the court relied on two more sources of authority. And its discussion of those was longer than its discussion of Lockhart and Mosley, and its view of the additional authorities led it to overrule McClain.

The court turned to the Kansas Rules of Professional Conduct, which are identical to the Model Rules promulgated by the American Bar Association with respect to the rule at issue here. Rule 3.4(e) limits the ability of lawyers to express personal opinions during trial:

A lawyer shall not ... in trial, allude to any matter that the lawyer does not reasonably believe is relevant or that will not be supported by admissible evidence, assert personal knowledge of facts in issue except

\footnotetext{
24. 947 P.2d at 465.

25. Id.

26. Pabst, 996 P.2d at 326.

27. 965 P.2d 848 (Kan. Ct. App. 1998), overruled on other grounds by State v. Simpson, 32 P.3d 1226, 1234-35 (Kan. Ct. App. 2001).

28. Pabst, 996 P.2d at 326.

29. 965 P. $2 d$ at 853.

30. Id.
} 
when testifying as a witness, or state a personal opinion as to the justness of a cause, the credibility of a witness, the culpability of a civil litigant or the guilt or innocence of an accused.

The Pabst court concluded that the rule precluding attorneys from stating "a personal opinion" about witness credibility prohibits them from talking about witness credibility altogether: "Our rules of conduct clearly and unequivocally say that it is improper for a lawyer to comment on a witness' credibility." 32

The court also noted a similar ABA standard applicable to prosecutors: "The prosecutor should not express his or her personal belief or opinion as to the truth or falsity of any testimony or evidence or the guilt of the defendant." 33 Comments to the ABA standard indicate that its prohibition on expressions of personal opinion is explicitly based on Model Rule 3.4(e). ${ }^{34}$

Based upon these authorities, the court concluded that the prosecutor improperly gave his personal opinion about the defendant's credibility as a witness:

Pabst's credibility was crucial to the case. The prosecutor placed before the jury unsworn testimony which it should not have considered: his personal opinion on Pabst's credibility and the credibility of the State's evidence. Stating facts not in evidence is clearly improper. Accusing Pabst of lying goes far beyond the traditional wide latitude afforded to prosecutors in closing argument. Inherent in this wide latitude is the freedom to craft an argument that includes reasonable inferences based on the evidence. When a case develops that turns on which of two conflicting stories is true, it may be reasonable to argue, based on evidence, that certain testimony is not believable. However, the ultimate conclusion as to any witness' veracity rests solely with the jury. ${ }^{35}$

The court recognized that its statement was not strictly true that "[a]ccusing Pabst of lying goes far beyond the traditional wide latitude afforded to prosecutors in closing argument." The court noted the

31. Model Rules of Prof'L Conduct R. 3.4(e), adopted in Kansas as Kansas Rule of Professional Conduct 3.4(e), KAN. S. CT. R. 226 (emphasis added as provided by the court in Pabst, 996 P.2d at 326).

32. 996 P.2d at 326 .

33. aba Standards for Criminal Justice, Prosecution Function, and Defense FunCTION 106, Standard 3-5.8(b) (3d ed. 1993).

34. Id. at 108, Std. 3-5.8 cmt. ("Such argument is expressly forbidden by the ABA model ethics codes ....") (citing MOdel Rules OF PROF'L CONDuCT 3.4(e) and its predecessor rule, MODEL CODE OF PROF'L RESPONSIBILITY DR 7-106(C)(4)).

35. Pabst, 996 P.2d at 326 (citations omitted). 
McClain holding two paragraphs later that "[c]ounsel may comment on the credibility of a witness where his remarks are based on the facts in evidence...."36 And the prosecutor in McClain also said that the defendant had "lied." 37 But the Pabst court concluded that this would violate Model Rule 3.4(e) and the ABA standards for prosecutors. So the court overruled McClain. It cited Model Rule 3.4(e) as the basis for doing so: "McClain's suggestion that it is proper to comment on a witness' credibility is not in accord with KRPC 3.4(e) and is disapproved." 38 This ruling in Pabst was not based upon some change in the ethical rules for lawyers between the days of McClain and the adoption of Rule 3.4(e); the rule in place at the time of the McClain decision was virtually identical to Rule 3.4(e). ${ }^{39}$

Pabst also determined that a two-part test applied when considering a claim of prosecutorial misconduct. The first step is to determine whether the remarks were improper. The second step is to determine whether the remarks were "so gross and flagrant as to prejudice the jury" and deny a fair trial. ${ }^{40}$ This Article is not about that two-part test; it's about whether lawyers may comment on witness credibility in argument. But the court's path in analyzing the second part of that test, where it concluded that Maxwell's comments were "so gross and flagrant" as to prejudice the jury, led to more discussion of Model Rule 3.4(e) and the court's application of it.

The court emphasized several factors in support of its conclusion that the prosecutor's conduct was so improper that a new trial was required. First, whether Pabst's story was a fabrication was "the ultimate issue," so it was improper for Maxwell to "introduce evidence" via his own testimony on that issue. As the court explained, "The point of not allowing a prosecutor to comment on the credibility of a witness is that expressions of personal opinion by the prosecutor are a form of unsworn, unchecked testimony, not commentary on the evidence of the case." 41

36. Id. (quoting McClain, 533 P.2d at 1282).

37. See note 20 and accompanying text.

38. Pabst, 996 P.2d at 326.

39. DR 7-106(C)(4) was quoted by the court in McClain. 533 P.2d at 1282. It prohibited a lawyer from stating a "personal opinion as to the justness of a cause, as to the credibility of a witness, as to the culpability of a civil litigant, or as to the guilt or innocence of an accused," but it said the attorney "may argue, on his analysis of the evidence, for any position or conclusion with respect to the matters stated herein." DR 7-106(C)(3), which was not discussed in McClain, separately prohibited an attorney from stating "his personal knowledge of the facts in issue, except when testifying as a witness." MODEL CODE OF PROF'L RESPONSIBILITY DR 7-106(C)(3), available at http://www.law.cornell.edu/ethics/aba/mcpr/MCPR.HTM.

40. Pabst, 996 P.2d at 325.

41. Id. at 328 (emphasis in original). 
The court said that presenting such "testimony" via argument was "expressly forbidden" by Rule 3.4(e) and the ABA standards. ${ }^{42}$ Second, the trial court overruled a defense objection to "The State tells you he lied," which may have left the jury thinking all of the Maxwell's statements about lying were proper. ${ }^{43}$ Third, in cross-examination of Pabst, Maxwell asked him whether the jury could convict him if it didn't believe him. Although an objection was sustained and Pabst didn't answer, Maxwell argued in closing that "you heard him agree that if . . . this jury found that he lied, then you would find him guilty." "44 Maxwell continued, "If you don't believe him, then he's guilty. And he admits it." didn't answer the question and the court sustained an objection to it-it also shifted the burden of proof to Pabst. ${ }^{46}$ Thus, if the jury accepted that argument, it didn't need to find that the State had proved beyond a reasonable doubt that Pabst committed first-degree murder; under the prosecutor's argument, the jury needed only to find that Pabst lied to convict him of murder. ${ }^{47}$ Whether a new trial is required is a factintensive review that may vary from case to case. But Pabst placed one clear marker in the landscape: attorneys may not comment on witness credibility in closing argument.

\section{The Legal PREMise of PABST IS CONTRARY to ACCEPTED LAW- SCHOOL TEACHING IN TRIAL ADVOCACY AND LEGAL ETHICS}

Pabst's basic rationale - that a lawyer is forbidden by ethics rules from talking about witness credibility in closing argument-lies at the intersection of legal ethics and trial advocacy. Both subjects are mainstays of the law-school curriculum. And those who teach these subjects clearly teach them contrary to Pabst.

\footnotetext{
42. Id.

43. Id. at 327-28.

44. Id. at 328 .

45. Id.

46. Id.

47. Id. at 328-29.
} 


\section{A. Law School Trial-Advocacy Programs Uniformly Teach Advocacy that Pabst Prohibits}

Steven Lubet, a law professor at Northwestern University, ${ }^{48}$ directs the law school's programs in both advocacy and ethics, and he is a recognized authority in both areas. ${ }^{49}$ He says it clearly: final argument is the place "to comment on, and compare, the motive and credibility of witnesses." 50 More to the point, "The credibility of witnesses should always be addressed on final argument."

How could it be otherwise? Credibility is at the heart of any trial. If all of the witnesses agreed upon all of the facts, no factual disputes would be submitted to a judge or jury. Closing argument is not the time to ignore the elephant in the room. It's the time to address that elephant.

Lubet's views on this subject formed the foundation for two Florida appellate decisions, ${ }^{52}$ the court's opinions relied upon and quoted extensively from Lubet's discussion differentiating between the improper statement of personal opinion by an attorney and proper argument. In

48. His published works include a treatise on trial advocacy, a coauthored set of problems in legal ethics, and a coauthored treatise on judicial ethics. STEVEN A. LUBET, MODERN TRIAL ADVOCACY: ANALYSIS AND PRACTICE (3d ed. 2004) [hereinafter MODERN TRIAL ADVOCACY]; Robert P. Burns, Thomas F. Geraghty \& Steven Lubet, Exercises and Problems in Professional Responsibility (2d ed. 2001); JAMES J. Alfini, SteVen Lubet, JefFrey M. Shaman \& Charles Gardner Geyh, Judicial CONDuCt \& Ethics (4th ed. 2007). Lubet's trial advocacy book has been called one of "[t]he two most widely used." Debra S. Katz \& Alan R. Kabat, Plaintiff's Trial Counsel Practice: Trial Tips for Litigating an Employment Discrimination Case, ALI-ABA Course, Dec. 2-4, 2004, available on Westlaw at SK033 ALI-ABA 947. Lubet has been a strong voice for making sure that the teaching of trial advocacy included a substantial focus on the ethical limits on advocacy. See Steven Lubet, Ethics and Theory Choice in Advocacy Education, 44 J. LegAl Educ. 81 (1994); Steven Lubet, What We Should Teach (But Don't) When We Teach Trial Advocacy, 37 J. LEGAL EDUC. 123 (1987).

49. Lubet's expertise in trial advocacy and legal ethics has been noted in several court opinions. See, e.g., Hall v. Forest River, Inc., No. 3:04-CV-259 RM, 2007 WL 2020172, at *6 (N.D. Ind. 2007) (citing Lubet's treatise on trial advocacy regarding what is proper in opening statement at trial); Conley v. United States, 332 F. Supp. 2d 302, 318 (D. Mass. 2004) (citing Lubet's treatise on trial advocacy to show that impeachment based on lack of recollection is different than impeachment for bias); Murphy v. Int'l Robotic Sys., Inc., 766 So. 2d 1010, 1029 (Fla. 2000) (citing Lubet's treatise on trial advocacy to conclude that use of personal pronoun "I" in closing argument is sometimes merely a figure of speech, not an expression of personal opinion); First Nat'l Bank of LaGrange v. Lowrey, 872 N.E.2d 447, 466 (Ill. App. Ct. 2007), appeal denied, 879 N.E.2d 930 (Ill. 2007) (finding Lubet's testimony as an expert witness on legal ethics sufficient to support legalmalpractice claim); Grievance Adm'r v. Lopatin, 612 N.W. 2d 120, 135 (Mich. 2000) (citing Lubet's treatise on judicial ethics regarding the harms of ex parte communications).

50. Lubet, MODERn Trial AdVOCACY, supra note 48, at 482.

51. Id. at 506 .

52. See Goutis v. Express Transport, Inc. 699 So. 2d 757, 763-64 (Fla. Dist. Ct. App. 1997), disapproved on other grounds by Murphy, 766 So. 2d at 1031; Forman v. Wallshein, 671 So. 2d 872 (Fla. Dist. Ct. App. 1996). 
the excerpt quoted by the court, Lubet provided both an example of an attorney expressing an improper personal opinion and a caution against applying the rule against personal opinion too literally:

It is improper and unethical for an attorney to "assert personal knowledge of facts in issue ... or state a personal opinion as to the justness of a cause, the credibility of a witness, the culpability of a civil litigant or the guilt or innocence of an accused."

The purpose of the rule is twofold. First, it prevents lawyers from putting their own credibility at issue in a case. The jury is required to decide a case on the basis of the law and evidence, not on their affinity for or faith in a particular lawyer. While every advocate strives to be trusted and believed, it subverts the jury system to make an overt, personal pitch.

Moreover, a statement of personal belief inevitably suggests that the lawyer has access to off-the-record information, and therefore invites the jury to decide the case on the basis of non-record evidence. Consider the following:

I have investigated the case thoroughly. I have spent hours with my client, and I have visited the scene of the accident. I could tell, just from talking with her, how seriously she has been injured. Believe me, I would not take up your time if my client were not telling the truth. I have handled many other cases of this type, and I can honestly say that this is one of the strongest plaintiff's cases that I have ever seen.

Here, the lawyer has not merely asked for the jury's confidence. Counsel has impliedly asked the jury to enter a verdict on the basis of out-of-court interviews and previously tried cases.

The rule against statements of personal belief is an important one. It should not be demeaned by a too-literal interpretation. It is difficult to purge your speech entirely of terms such as "I think" or "I believe." While good lawyers will strive to avoid these terms, it is not unethical to fall occasionally into first person references. Similarly, it is unnecessary to preface every assertion with statements such as "the evidence has shown," "we have proven," or the like.

53. Goutis, 699 So. 2d at 763-64 (quoting Lubet, Modern Trial AdVOCACY 432-33 (1st ed. 1993)) (emphasis in original). The same material may be found in the current edition of Lubet's treatise. See Lubet, Modern Trial Advocacy, supra note 48, at 519-20. The Florida Supreme Court, citing Lubet, ultimately adopted the view that the use of the personal pronoun "I" was often a figure of speech, not an improper argument. Murphy, 766 So. 2d at 1029. 
Lubet's teaching that closing argument is the time to discuss witness credibility is amply supported by others who teach advocacy. The other leading text on trial advocacy is by Thomas A. Mauet, ${ }^{54}$ who heads the trial-advocacy program at the University of Arizona law school. He advises lawyers to focus the closing argument on why your evidence has greater credibility than your opponent's:

Most trials are ultimately a contest to determine whose version of a disputed event or transaction is more likely true. Which side's version of reality will the jury accept as true? Inexperienced trial lawyers frequently make two interrelated mistakes. They spend too much time reviewing undisputed facts, and too little time arguing why the jury should accept their version of the key disputed facts. Hence, you need to focus on the key things: What are the key factual disputes in the case? How can I get the jury to accept my version? Once you have focused on the critical facts, you need to argue that you have more, or more credible, evidence so that the jury must resolve the dispute in your favor."

Mauet notes that witness credibility is one of the three most important issues to be addressed. ${ }^{56}$ He provides sample closing arguments that explicitly argue about witness credibility. ${ }^{57}$ And his trial advocacy instructor's manual provides sample problems in which students are told to argue why a particular witness' testimony was credible or that a criminal defendant's testimony should not be believed. $^{58}$

54. Debra S. Katz \& Alan R. Kabat, Plaintiff's Trial Counsel Practice: Trial Tips for Litigating an Employment Discrimination Case, ALI-ABA Course, Dec. 2-4, 2004, available on Westlaw at SK033 ALI-ABA 947.

55. Thomas A. MAUet, Trial TeChNiques 418 (6th ed. 2002).

56. Id. at $418-19$.

57. For example, in one sample closing argument, Mauet provides:

We have, then, a classic case of testimony that ... is contradictory, and it's your duty to decide where the truth lies. In other words, you've got to decide which witnesses are telling the truth.....

The witnesses we called were all hardworking, decent people who told you what happened. ... It is totally impossible for the defendant, shooting 'blindly' as he would have you believe, to just happen to shoot the only victim, and just happen to shoot him twice in the back. Not only does the physical and medical evidence contradict the defense, but the only witness who testified directly to this version of the events was the defendant himself. When you consider the credibility of his testimony, keep in mind that, if ever a man had a motive to distort the truth and fabricate a story, it's got to be the defendant in a criminal case charged with murder.

Id. at $436-37$.

58. Thomas A. Mauet \& Warren D. Wolfson, Materials in Trial AdVocacy: 
Paul Bergman, who founded the trial-advocacy program at the University of California at Los Angeles law school, presents detailed explanations of how to argue credibility in closing in his book on trial advocacy. ${ }^{59}$ He advises students to directly argue that a witness has lied when that is the only reasonable way to discredit that witness' testimony:

On occasion, the only inference you can reasonably ask a factfinder to accept is that an adverse witness lied. For instance, as a prosecutor you may be unable to argue sensibly that an alibi witness was mistaken about having been out of town with the defendant when the crime was committed. In such situations, you should explicitly acknowledge the "lying" inference. 60

Bergman's explanation mirrors Lubet's discussion of the difference between the improper expression of personal opinion and proper argument. In a hypothetical argument about why Jack went up the hill, Bergman presents an attorney who starts sentences with "I think," but the attorney is really just discussing inferences from the evidence, not personal knowledge from outside the trial:

"Jack would have you believe that he went up the hill to fetch a pail of water. However, as Jill testified, and as you might expect, the well was located at the bottom of the hill. I think that Jack was not telling the truth, and that Jill's testimony shows that Jack went up there for another purpose entirely. I think that purpose will become clear if you look at Hansel's testimony ...."61

Bergman finds this argument "common and proper."62 According to Bergman, "if you can mentally substitute the phrase, 'I submit that the evidence shows ...' for 'I think ...,' your argument is proper." ${ }^{\text {"63 }}$ Both Lubet and the Florida court opinions use "I" as a figure of speech in the same way.

Bergman follows with examples of improper argument, like "“[n]ever in my 32 years of practice have I represented a client who has been so careful" " or "I have never cross examined a witness who told as many lies as did Lem Bezzle." "64 In each of those examples, the attorney

PROBLEMS AND CASES 623-24, 627-28 (5th ed. 2002).

59. Paul Bergman, Trial AdVocacy in a Nutshell 248-51, 263-66 (3d ed. 1997).

60. Id. at 264 .

61. Id. at 280

62. Id.

63. Id.

64. Id. at $280-81$. 
was inserting additional factual information known only to the attorney rather than relying upon evidence presented in court.

Roger Haydock and John Sonsteng teach trial advocacy at the William Mitchell College of Law in St. Paul, Minnesota. They too have a trial-advocacy text that has gone through multiple editions. They too suggest that witness credibility is a key topic for closing: "An attorney may comment on the credibility of a witness, may demonstrate how an observation or statement is inaccurate, may attempt to show a witness is biased or prejudiced, or may comment on the witness' demeanor." 65 They provide sample closing arguments arguing directly either that a witness lied or that a witness was mistaken. ${ }^{66}$ And they emphasize the central nature of these questions: "Every trial involves contradictory evidence pitting the testimony of one witness against another. Some witnesses deserve to be called a liar. More often, a better tactic is to describe a witness as being mistaken." rather than merely mistaken is a tactical choice in the trial-advocacy course in law school, not a forbidden one.

\section{B. Law-School Ethics Instruction Is Contrary to Pabst's Interpretation of Ethics Rules}

Ronald D. Rotunda is a law professor at George Mason University and coauthor of an ethics course book for law students now in its ninth edition. ${ }^{68}$ Rotunda notes that Model Rule 3.4(e) prevents an attorney in closing from "assert[ing] his personal opinion or knowledge regarding facts at issue." But he quickly adds that "the lawyer may argue for any position or conclusion based on his analysis of the evidence." ${ }^{69}$ He then

65. Roger HAydock \& JOHN SONSTENG, TRIAL: AdVOCACY BEFORE JUdGES, JURORS, AND ARBITRATORS 613 (3d ed. 2004). Their "closing argument worksheet" includes consideration of "credibility of witnesses." Id. at 599.

66. Id. at 613-14. The argument that a party lied is direct: "YYou heard the plaintiff's boss, Alberta Dowlin, testify that she fired the plaintiff because the plaintiff lied on his employment application. The plaintiff had lied on that application not once but on every page. ... Plaintiff is not an honest or honorable person in his professional or personal life." Id. at 613. Haydock and Sonsteng also provide examples of improper personal argument by counsel, such as, "There is no question in my mind that the plaintiff lied to you. I heard what you heard, and I saw what you saw. I am convinced the plaintiff lied." Id. at 643.

67. Id. at 629 .

68. Thomas D. Morgan \& Ronald D. Rotunda, Professional Responsibility: PROBLEMS AND MATERIALS (9th ed. 2006).

69. Ronald D. Rotunda \& John S. DZiEnkowski, Professional Responsibility: A STUDENT's GUIDE 2007-2008 § 3.4-6 (2007). Although Rotunda now has a coauthor in this treatise, the material quoted was contained in a prior edition authored solely by him. RONALD D. ROTUNDA: THE LAWYER's DESKBOOK ON PROFESSIONAL RESPONSIBILITY 2002-2003 § 25-6 (2002). Thus, I 
provides examples - fully consistent with the ones provided by Lubet and Bergman in advocacy texts - to define what's proper and what's forbidden under Rule 3.4(e):

Consider two examples that illustrate this principle. First, assume that in closing argument the lawyer states: "How can you believe Witness? I've seen many people testify over the years, and in my experience, Witness is lying. I don't believe him, can you?" The lawyer's action is improper, even if Lawyer really believes that Witness is lying because the lawyer may not assert his personal opinions regarding the facts at issue.

Now, assume that in closing argument the lawyer states: "How can you believe Witness? His testimony contradicts the sworn testimony of three other people who, unlike Witness, have no financial interest in this case." The lawyer's action is proper, because he is just arguing from the evidence that is in the record.

Rotunda concludes that this result is justified because "[t]he law does not want lawyers purporting to be witnesses, vouching for their client's veracity," yet lawyers may "argue from the evidence," even in ways that are "colorful."

\section{ThE STANDARD LAW-SCHOOL TEACHING ON THESE SUBJECTS IS CONFIRMED ELSEWHERE}

The basics of trial advocacy taught by Lubet, Mauet, Bergman, Haydock, and Sonsteng are the same. Credibility is a key issue for closing argument, and it must be addressed. The authors of numerous reference works that are aimed at practitioners agree that credibility should be addressed in closing argument. ${ }^{72}$

have attributed this discussion to Rotunda, even though it is clear that Professor Dzienkowski of the University of Texas law school has now joined in support of it.

70. ROTUNDA \& DZIENKOWSKI, supra note 69; RotUNDA, supra note 69.

71. RotUNDA \& DZIENKOWSKI, supra note 69; ROTUNDA, supra note 69.

72. E.g., 75A AM. JUR. 2D Trial $\$ 577$ (2007) ("It is widely recognized that counsel in arguing a case to the jury may comment on the credibility of a witness where his or her remarks are based on facts appearing in the evidence.”); 23A C.J.S. Criminal Law § 1718 (2006) (“As a general rule, the credibility of witnesses is a matter within the proper scope of argument, provided such assertions are based upon reasons arising from the evidence."); JACOB A. STEIN, Closing ARGUMENTS: THE ART AND THE LAW $§ 1: 48$ (2d ed. 2005) ("It is proper, and generally most important, for counsel to comment on the credibility of witnesses in making closing argument. ... When a defendant in a criminal action appears as a witness in his or her own behalf the prosecutor may comment on their credibility the same as that of any other witness."); PAUL W. VAPNEK, MARK L. TUFT, EllEn R. PECK \& Howard B. Wiener, CALIFornia Practice Guide: Professional RESPONSIBILITY Ch. 8-C (2007) (Westlaw) ("It is a trial lawyer's job to argue the credibility of witnesses to the jury."). 
Rotunda's view of Model Rule 3.4(e) is consistent with the most authoritative recent work on legal ethics: the Restatement (Third) of the Law Governing Lawyers. In section 107, the Restatement notes that an attorney may not "state a personal opinion" about the list of items contained in Rule 3.4(e). But the rest of the black-letter rule in section 107 makes clear that the lawyer may comment on all of these subjects if supported by the evidence:

In representing a client in a matter before a tribunal, a lawyer may not, in the presence of the trier of fact[,] . . . state a personal opinion about the justness of a cause, the credibility of a witness, the culpability of a civil litigant, or the guilt or innocence of an accused, but the lawyer may argue any position or conclusion adequately supported by the lawyer's analysis of the evidence .... ${ }^{73}$

Whether a witness has lied is certainly a "position or conclusion" that may be supported by the evidence. Other conclusions that are related to credibility - the witness couldn't see the events well, was too excited to observe them, or is biased-would also fit within what section 107 says the attorney may argue.

For further confirmation of this interpretation of Model Rule 3.4(e), let's turn to a standard method of interpreting rules or statutes. The rule treats four topics similarly in precluding the attorney from expressing a personal opinion about them: "A lawyer shall not... state a personal opinion as to [1] the justness of a cause, [2] the credibility of a witness, [3] the culpability of a civil litigant or [4] the guilt or innocence of an accused." Somehow, the Pabst court interpreted the ban on personal opinions about credibility to a conclusion that it was improper even to comment on a witness' credibility. Yet the court has explicitly recognized that a prosecutor may comment directly on the guilt of an accused by asking for a guilty verdict. ${ }^{74}$ And the court has said that "it is permissible, if not expected, for a prosecutor to argue for justice in general." ${ }^{, 75}$ If the attorney may comment on some of the items listed in Rule 3.4(e) — the justness of a cause or the guilt of the accused-without

73. 2 Restatement (ThiRD) OF the LaW Governing Lawyers $§ 107$ (2000) (emphasis added). To the extent there is tension between the two subparts of section 107-prohibiting personal opinion on the one hand, while allowing argument of any position supported by the evidence- the comment to section 107 makes clear that room must be left to present arguments: "Latitude is to be left to the advocate in doubtful cases, subject to the superintending power of the presiding officer to prevent improper or misleading argument." Id. $\mathrm{cmt}$. b.

74. State v. Nguyen, 172 P.3d 1165, 1171-72 (Kan. 2007) (finding no impropriety in prosecutor's closing argument that "the only verdict ... that the evidence points to, the verdict that justice in this case requires, is that you find the defendant guilty of first degree murder").

75. Id. at 1172 . 
running afoul of the rule against expression of personal opinions, it would make no sense to interpret the rule to prohibit all comment on another item in the same list: witness credibility.

This view is reinforced when we consider how broadly a prohibition of all comment on witness credibility would be. Credibility includes many things, such as the ability to observe events (perhaps without eyeglasses, for example) or whether a person may have been distracted or excited. Credibility may also be attacked based on bias or motive, inconsistent prior statements of the witness, contrary testimony from other witnesses, a prior conviction for dishonesty, or some other attack on the witness' character, when permitted by evidentiary rules. ${ }^{76}$ It would be absurd to suggest that an attorney may not even talk about such matters in closing argument.

Moreover, Model Rule 3.4(e) applies to all attorneys, not just prosecutors. Logically, because Pabst is based on the rules of professional conduct governing all attorneys, its holding cannot be limited just to prosecutors or even only to criminal cases. Indeed, citing Pabst, the Kansas Court of Appeals held in State v. Johnson ${ }^{77}$ that defense attorneys in criminal cases are "like the prosecutor,... prohibited from commenting on the credibility of a witness." 78 The defense attorney had referred to a "web of lie[s]" spun by the State's witnesses, including a specific attack on the State's main witness. ${ }^{79}$ But applying such a restriction to counsel for a criminal defendant would in some cases violate a defendant's right to present closing argument to the jury ${ }^{80}$ It would certainly seem odd to preclude the defense counsel from simply saying that a witness had lied in a case in which the defendant might be subject to life imprisonment or even death. After all, we rely upon an adversary system in which the defense counsel must present the strongest possible defense against a case brought by the government.

I have not conducted a fifty-state survey of caselaw to make sure that there are no other states that presently interpret Model Rule 3.4(e) in the way the Pabst court did. However, I would note one state in which a ruling similar to Pabst was later rejected. Some district courts of appeal in Florida ruled that it was improper to say that a witness had lied in a series of cases relying upon the ethics rule precluding expression of a

\footnotetext{
76. See generally 1 MCCORMICK ON EVIDENCE $§ 33$ (Kenneth S. Broun ed., 6th ed. 2006).

77. 86 P.3d 551 (Kan. Ct. App. 2004).

78. Id. at 553 .

79. Id. at 552

80. See infra notes $107-19$ and accompanying text.
} 
lawyer's personal opinions in argument. ${ }^{81}$ The Florida Supreme Court overruled those cases in 2000 in Murphy v. International Robotic Systems, Inc. ${ }^{82}$ After reviewing Rule 3.4(e), the court found that it was not impermissible under the rule to say that a witness had lied or call a witness a liar "provided such characterizations are supported by the record." ${ }^{, 3}$ The court also agreed with Lubet and Mauet that merely using the personal pronoun " $\mathrm{I}$ " during closing argument "is not, in and of itself, improper" because it often is "merely a figure of speech.", 84

\section{KANSAS IS Not Well SERVED By CRAFTING ITS OWN UNIQUE RULE HERE}

The discussion so far has shown that the rationale of Pabst-that attorneys may not comment on witness credibility in argument-is contrary to the way trial advocacy and legal ethics are taught in most law schools and that there is substantial support for the way the law schools are teaching about this. But maybe Kansas should have its own, unique rule. In this final section, I will try to dispel that notion.

\section{A. Jurors Deserve a Full Presentation of the Issues}

The pattern jury instructions in Kansas provide an instruction on witness credibility that is recommended in every civil and criminal jury trial. ${ }^{85}$ Jurors are told that they are "to determine the weight and credit to be given the testimony of each witness." "have a right to use common knowledge and experience" in making credibility decisions. ${ }^{87}$

In addition to these instructions, there is a growing movementbased upon extensive research-toward providing better guidance to juries about how to do their work. Since Judge Michael Dann's

81. King v. Nat'l Sec. Fire \& Cas. Co., 656 So. 2d 1335, 1337 (Fla. Dist. Ct. App. 1995), rev'd, Murphy v. Int'l Robotic Sys., Inc., 766 So. 2d 1010 (Fla. 2000); Kaas v. Atlas Chemical Co., 623 So. 2d 525, 526 (Fla. Dist. Ct. App. 1993), rev'd, Murphy, 766 So. 2d 1010.

82. 766 So. 2 d 1010 (Fla. 2000).

83. Id. at 1028 .

84. Id. at 1029.

85. PATtern Instructions Kansas: Civil 102.20 (3d ed. 2005); PATtern Instructions FOR KANSAS: CRIMINAL 52.09 (3d ed. 2006).

86. Pattern InStRuctions Kansas: Civil 102.20 (3d ed. 2005); PATtern Instructions FOR KANSAS: CRIMINAL 52.09 (3d ed. 2006).

87. PATTERN INSTRUCTIONS KANSAS: Civil 102.20 (3d ed. 2005); PATTERn InSTRUCTIONS FOR KANSAS: CRIMINAL 52.09 (3d ed. 2006). 
influential 1993 article ${ }^{88}$ there has been a trend toward making sure that jurors have all the tools they need to do their jobs, including allowing jurors to take notes, to ask questions, and to receive more understandable jury instructions. ${ }^{89}$

In researching the effect of directly addressing witness credibility on juries, Professor Valerie Hans conducted mock jury trials in which a whiplash case was presented in two ways. ${ }^{90}$ Before conducting the mock jury trials, Hans determined that people were generally skeptical about whiplash injuries with feedback from opinion surveys and focus groups. As one person said in a focus group, "I may see somebody with a neck brace. My first reaction is I don't believe you." "91 The mock jury trials sought to determine whether plaintiffs' attorneys could effectively respond to the preconceptions that jurors would bring with them. In one version of the mock-trial presentation, the attorney "directly addressed concerns about the plaintiff's credibility and responsibility in the attorney's opening statement and closing argument." 92 By directly addressing credibility and providing corroborating testimony, the concern of many jurors "that the plaintiff was trying to pull one over on the jury" was satisfied and mock jurors responded more favorably to the plaintiff's claim. ${ }^{93}$ Thus, it would appear that discussion of credibility is not only relevant, but it is also capable of changing the framework within which a jury evaluates a particular case.

We want jurors to be impartial. Yet we know that they do bring their preconceptions with them. Professor Hans' research shows that effective arguments-including ones specifically directed toward witness credibility - can move jurors away from their preconceptions. An adversarial justice system is better off when both sides can address such issues than it is when jurors go back to the jury room armed with their preconceptions and lacking the attorneys' best arguments.

Ordinarily, in closing argument, the attorney is allowed to address both the legal instructions given to the jury and the facts of the case. A

88. B. Michael Dann, "Learning Lessons" and "Speaking Rights": Creating Educated and Democratic Juries, 68 IND. L.J. 1229 (1993).

89. See generally AMERICAN BAR ASSOCIATION, PRINCIPLES FOR JURIES \& JURy TRIals (2005); B. Michael Dann \& Valerie P. Hans, Recent Evaluative Research on Jury Trial Innovations, CT. Rev., Spring 2004, at 12; Gregory E. Mize \& Christopher J. Connelly, Jury Trial Innovations: Charting a Rising Tide, CT. REV., Spring 2004, at 4.

90. Valerie P. Hans, The Pound Connective Tissue Injury Research Project: Final REPORT (2007) [hereinafter HANS, FINAL REPORT].

91. Id. at 17 .

92. The Jury, Alive and Well: Three Decades of Study by Two of the Country's Leading Jury Researchers Have Revealed a Thriving Jury System, TRIAL, March 2008, at 42, 47-48.

93. Id.; see also HANS, FINAL REPORT, supra note 90, at 26-32. 
specific instruction is given on witness credibility, just as an instruction is always given either providing the elements of the civil claim or criminal charge at issue. Given the salutary trend toward providing the greatest possible help to juries in doing their job, lawyers should be allowed to address all of the issues that are central to the jury's work. Once the court has told the jurors that they may use "common knowledge and experience" in deciding which witnesses were credible, the attorneys should be free to make their best argument about how and why bringing common knowledge and experience to bear on the evidence presented to that jury should result in a verdict for either side.

\section{B. Precluding Comment on Credibility During Closing Would Leave a Key Issue Unaddressed}

Courts openly acknowledge that credibility often is a major issue in the case. ${ }^{94}$ This logically follows from the general purpose of a trial, which is to resolve factual disputes. Such disputes arise from conflicting testimony, which usually places some issues of credibility before the fact-finder.

Let's look at a few specific examples, two from my personal experience and one more famous case. In each, the jury would have been floating adrift had the counsel not commented on witness credibility. The credibility of witnesses or of a criminal defendant was the key issue in each of these cases.

\section{Sifers Corp. v. Arizona Bakery Sales Co. ${ }^{95}$}

This was one of my favorite cases in private practice-mainly because the opposing attorney was a former student body president at Kansas State University, and the facts of the case allowed me to introduce into evidence the front page of the Kansas City Star from April 5, 1988, reporting on the University of Kansas winning the national basketball championship. My client was an Arizona company that had

94. A Westlaw search of all cases returned 1,365 cases in which credibility appeared within ten words of "key issue," "major issue," or "important issue." See, e.g., Tassin v. Cain, 517 F.3d 770, 778 (5th Cir. 2008) (noting that a witness's credibility was "an important issue" in the case); United States v. Rodriguez, 539 F. Supp. 2d 592 (D. Conn. 2008) (noting that the "defendant's credibility [was] the single most important issue" in the case); Shaw v. Campbell, No. CIV S-05-1506 MCE GGH P, 2008 WL 744731 (E.D. Cal. Mar. 18, 2008) (noting that the victim's credibility was the major issue in the case); State v. Jackson, 177 P.3d 419, Syl. II 5 (Kan. Ct. App. 2008) (noting that "the credibility of the victim was a key issue at trial").

95. 133 F.R.D. 607 (D. Kan. 1991). 
contracted with a Kansas firm to supply commemorative plastic cups to celebrate the move of the National Football League's Cardinals franchise from St. Louis to Phoenix. The contract had been entered into only days before KU won its national championship. The Arizona company claimed that everyone had agreed that because of the immediate excitement the franchise move had generated in Phoenix, time was of the essence of the contract to ship cups to Arizona. But the Kansas company had rushed commemorative KU national championship cups into production before it produced the Arizona Cardinals cups. Testimony by the principals of the two companies differed sharply about what had been agreed upon.

In closing argument, I faced the decision whether to argue explicitly that the principal of the opposing party was lying about his company's agreement or whether simply to argue that his recollection was mistaken. Trial advocacy texts generally advise going for the jugular, i.e., saying directly that somebody is lying, only if you're sure you've got the goods. ${ }^{96}$ I felt that there was really no way to reconcile their testimony, and that a good case could be made that greed provided the motive for the lie in the form of trying to keep both the bird in the hand (the time-isof-the-essence contract to produce Arizona Cardinals cups) and the bird in the bush (the ability to make additional profit by producing KU cups, an opportunity that arose within days of the entry of the Arizona contract). Thus, the closing argument focused on the differing testimony from the principals, the evidence that corroborated my client's testimony, and the motive that suggested that the other principal was lying. The jury agreed, at least as to the overall result, and the court upheld the verdict. ${ }^{97}$

96. See Paul Bergman, Trial Advocacy in a Nutshell 263 (2d ed. 1997) (“As a general rule, factfinders are more willing to conclude that a witness is mistaken than that a witness is lying."); JAMES W. JEANS, SR., TRIAL ADVOCACY § 15.20 (2d ed. 1993) ("Remember the advice followed by revolutionists, 'When you shoot the King, shoot to kill!' If you are questioning the truthfulness of a witness you had best have the evidence to make your attack successful."); STEVEN LUBET, MODERN TRIAL ADVOCACY 472 (3d ed. 2004) ("Most lawyers consider it to be particularly difficult to persuade a jury to draw such adverse conclusions about any but the most disreputable witnesses."); James W. McElhaney, McElhaney's Trial NotebooK 696 (4th ed. 2006) ("If the jury feels the defendant is the good guy, they won't want to believe he was lying.").

97. The court found sufficient evidence to conclude that the contract had been breached by delay in shipment of the cups. Sifers Corp., 133 F.R.D. at 609. 


\section{J.S. v. Dillard's Corp.}

I represented J.S. ${ }^{98}$ in this case; she had been arrested for shoplifting and acquitted. She then sued Dillard's for false arrest. The jury had to decide whether J.S. was a shoplifter or whether she was wrongly arrested. J.S.'s story was that she had bought some merchandise at one Dillard's store and had returned it for credit at another. But Dillard's came up with striking evidence at trial that there was no cash-register transaction record for the day in question that matched her story. The credibility of J.S. was the key issue, and the cash-register records for every register in the Dillard's store provided a strong piece of evidence for Dillard's case that J.S. was not only a shoplifter but also a liar in her claim of false arrest. Closing argument in the case had to focus on the credibility of J.S., and both attorneys did so. There were decent arguments to be made for each side; the jury deliberated for more than three hours. But the jury ultimately ruled ten-to-two in favor of Dillard's, with the majority finding J.S.'s story not as compelling as the evidence to the contrary.

\section{State of California v. John DeLorean}

One collection of the top ten closing arguments in modern history includes the 1984 closing argument of DeLorean defense lawyer Donald Re. ${ }^{99}$ DeLorean was a former General Motors executive who had left GM to run his own car-manufacturing company. Strapped for cash, he learned of an opportunity to make some quick money from a neighbor, James Hoffman, who turned out to be both a drug smuggler and a government informant. All of the meetings were recorded on tape except for DeLorean's first meeting with Hoffman, and a videotape of DeLorean inspecting a suitcase full of cocaine, proclaiming it "better than gold," and lifting a glass of champagne in a toast for "a lot of success for everyone" was shown on the CBS Evening News before trial. Not an easy case to defend, but DeLorean was acquitted.

98. I've omitted her name since there are obvious negative connotations to shoplifting, and we were unsuccessful before a jury on the false-arrest claim. Her claim was tried to a jury in Wyandotte County, Kansas, in approximately 1992.

99. Michael S. Lief, H. Mitchell Caldwell \& Ben Bycel, Ladies and Gentlemen of THE JURY: GREATEST CLOSING ARGUMENTS IN MODERN LAW 305-44 (1998). The facts of the case in the text are taken from the book's summary. Id. at 305-13. 
Re presented a scathing indictment of Hoffman's credibility. Hoffman had bragged to federal agents, "I'm going to get John DeLorean for you guys .... The problems he's got, I can get him to do anything I want." 100 Re hammered on the credibility of both Hoffman and the government agents because Hoffman's first meeting with DeLorean was not taped and the government agents had lied numerous times. Re began by pointing out inconsistencies in Hoffman's story over time about how he had first met DeLorean and then how he had first introduced the subject of drugs to DeLorean, and Re proceeded to additional attacks on Hoffman's credibility:

Well, what Mr. Hoffman has to do now is cook up a new story. He talks about purchasing the Pauma Valley house from DeLorean. There is no mention of that in his earlier statements. Why not? Because he didn't make it up until he got to trial, because he didn't make it up until after the grand jury. ....

What you have seen from Hoffman, then, is a lie created on the spur of the moment by a con man. What it should show you is that DeLorean had no reason to ask Jim Hoffman about drugs because DeLorean and Hoffman had never talked about drugs in 1980 . . . .

The judge will read you some instructions, and I expect one of his instructions is about the testimony of a perjurer. Mr. Hoffman is an admitted perjurer. He lied. He lied under oath, and he lied under oath with a reason. That's what the government kept telling you; he had a reason, and I have been dying to hear what that reason was, and the reason was if he didn't lie under oath, Mr. Hetrick [a suspected drug supplier] wouldn't fly a load for him. So that shows you that James Hoffman not only is a perjurer but he is a man who is willing to perjure himself to further his own illegal narcotic activities ....

Hoffman has made constant demands for money [from the government] during the course of this case. He has misrepresented a situation to the government, and yet the government and Mr. Hoffman come before you and say that he is a man who is to be believed. And yet he is not to be believed, ladies and gentlemen, and he is particularly not to be believed in those situations in which he was the only one who was giving the information.

Hoffman was willing to lie, he is a con man. Con men tell you the story that fits at the time.

100. Id. at 308-09.

101. Id. at 316-19. 
From that beginning, Re proceeded to provide additional reasons not to believe Hoffman. He noted that they could also consider that Hoffman had been convicted of another felony, selling narcotics. ${ }^{102} \mathrm{He}$ noted that Hoffman was an informant who was gaining government concessions in exchange for his testimony, including $\$ 180,000$ during the pendency of the undercover operation. ${ }^{103}$ He noted that the judge would also tell the jury that it could consider a witness's inconsistent statements as an indicator of their credibility and that Hoffman had made lots of inconsistent statements about "key elements" in the case. ${ }^{104} \mathrm{He}$ concluded the introductory remarks about Hoffman's credibility this way:

So you have the fact that he is a perjurer, he is a felon, and informant, he has made inconsistent statements, and the fact that you can reject his entire testimony because, ladies and gentlemen, there is no doubt that he lied to you on that stand at least about what happened in 1980, and as we go through this, you will see that he lied about a lot of other things.

In the remainder of Re's closing argument, he proceeded chronologically through the government's case, showing how it depended upon the uncorroborated testimony of Hoffman, how government agents had shown a zeal to "get" DeLorean, and how DeLorean's actions could be seen as reactions to misrepresentations by Hoffman or government agents. ${ }^{106}$ It is hard to conceive of a theory of defense for the DeLorean case that would not have required an attack on Hoffman's credibility.

\section{Precluding Comment on Witness Credibility Violates the Constitutional Rights of Criminal Defendants}

Let's consider for a moment how the DeLorean case might have been tried if the rule in Pabst - that an attorney could not comment on witness credibility - had been applied. DeLorean's attorney, Donald Re, was a top-notch attorney, ${ }^{107}$ and he turned an attack on Hoffman's

102. Id. at 318

103. Id.

104. Id. at 319 .

105. Id

106. Id. at 319-44.

107. Id. at 309-10. He began practicing criminal defense in 1971 and taught constitutional law 
credibility and the government's methods into a winning strategy. Perhaps someone could have crafted a defense strategy for the DeLorean case that would not have required such credibility arguments. But we know that Re did not think such a strategy would be the best one to use, and the defendant and defendant's attorney-not the government-have the right to decide how to defend the case. Much of Re's closing argument would have been precluded by Pabst.

But doing so would interfere with the defendant's constitutional right to present closing argument. The United States Supreme Court held in Herring $v$. New York $^{108}$ that the right to counsel as guaranteed by the Sixth Amendment includes the right to make closing argument in both jury- and judge-tried cases. And Herring may be fairly interpreted as holding that a defendant has a right to make closing argument regarding witness credibility. There were only four witnesses in Herring - two for the prosecution and two for the defense, including the defendant. ${ }^{109}$ The defense counsel attacked the credibility of the prosecution witnesses with their own prior inconsistent statements, conflicts between the testimony of the two prosecution witnesses, and contrary testimony from the defendant. ${ }^{110}$ The Court held "that closing argument for the defense is a basic element of the adversary factfinding process in a criminal trial."111 When it applied the rule that closing argument is a right to the facts of the case, the Court emphasized the ways in which closing argument in Herring might have addressed witness credibility and referred to the credibility arguments as among the "appropriate arguments" that might have been made:

[The defendant's] lawyer might usefully have pointed to the direct conflict in the trial testimony of the only two prosecution witnesses concerning how and when the appellant was found on the evening of the alleged offense. He might also have stressed the many inconsistencies, elicited on cross-examination, between the trial testimony of the complaining witness and his earlier sworn statements. He might reasonably have argued that the testimony of the appellant's employer was entitled to greater credibility than that of the complaining witness, who, according to the appellant, had threatened to "fix" him because of personal differences in the past. There is no way to know

\footnotetext{
at the Univerisity of California at Los Angeles law school for three years in the mid-1970s. In addition to his representation of DeLorean, he represented Andrew Daulton Lee on espionage charges (made famous in the movie The Falcon and the Snowman), McKinley Lee, better known as Snoop Doggy Dogg, on murder charges, and O.J. Simpson confidant A.C. Cowlings. Id.

108. 422 U.S. 853 (1975).

109. Id. at 854-56.

110. Id.

111. Id. at 858
} 
whether these or any other appropriate arguments in summation might have affected the ultimate judgment in this case. The credibility assessment was solely for the trier of fact. But before that determination was made, the appellant, through counsel, had a right to be heard in summation of the evidence from the point of view most favorable to him. ${ }^{112}$

The Court also cited favorably to a Maryland decision, Yopps $v$. State ${ }^{113}$ in which the Maryland Court of Appeals found a violation of the right to counsel when the trial judge "refused to hear any argument on the ground that only a question of credibility was involved, and that therefore counsel's argument would not change his mind." ${ }^{, 14}$ It is significant that the Court's ruling in Herring emphasized the ways in which defense counsel could have appropriately argued witness credibility in his closing argument and that the precedent most fully discussed, Yopps, also reversed when the defense counsel was not allowed to present argument on credibility. As the Florida Court of Appeals has put it in a later case, "No area is more deserving of "wide latitude' [for argument] than the defendant's ability in a criminal case to argue the 'credibility and biases of the witnesses who testified at trial.","115

Kansas courts have also recognized the right of defense counsel to make closing argument. ${ }^{116}$ What Kansas courts have not yet addressed is whether defense counsel has a specific right to present an argument regarding witness credibility. But Kansas courts have held that the defendant's other constitutional rights in a criminal trial are violated by restrictions that prevent the defendant from challenging the credibility of the State's witnesses. Under the Sixth Amendment, the defendant in a criminal case has a right to confront the State's witnesses, which means that the defendant must be given an effective opportunity to crossexamine those witnesses. ${ }^{117}$ Kansas appellate courts have found that

\footnotetext{
112. Id. at 864 (emphasis added).

113. 178 A.2d 879 (Md. 1962)

114. Herring, 422 U.S. at 860.

115. Williams v. State, 912 So. $2 d$ 66, 68 (Fla. Dist. Ct. App. 2005) (finding that district court violated defendant's constitutional rights by preventing defense lawyer from arguing that complaining witness was true aggressor and had fabricated his story to avoid getting into trouble) (quoting Goodrich v. State, 854 So. 2d 663, 665 (Fla. Dist. Ct. App. 2003)).

116. State v. Whitmore, 36 P. 748, Syl. (Kan. 1894) ("[C]ounsel has the right to fairly argue his theory of the law of the case to the jury ...."); State v. Verry, 13 P. 838, 841 (Kan. 1887); State v. Cunningham, No. 92,516, 2005 WL 1561444, at *3 (Kan. Ct. App. July 1, 2005); State v. Jeffrey, 75 P.3d 284, 286 (Syl. II 5), 290 (Kan. Ct. App. 2003)

117. Crawford v. Washington, 541 U.S. 36, 50-51 (2004); United States v. Owens, 484 U.S. 554, 559 (1988); State v. Atkinson, 80 P.3d 1143, 1149 (Kan. 2003).
} 
right to confrontation violated when cross-examination is precluded regarding a significant prior inconsistent statement of the complaining witness or some other matter that might significantly impact the complaining witness's credibility. ${ }^{118}$ There is no reason to apply a different rule when a defendant attempts to exercise the right to make an appropriate closing argument about witness credibility. ${ }^{119}$

\section{The Pabst Rationale Is Unworkable in Practice}

If the argument in the preceding section is correct, the court may not constitutionally prohibit defense counsel in a criminal case from commenting on witness credibility in closing argument when the evidence would support such an argument. That presents an obvious practical problem with enforcement of the Pabst rule in criminal casesit can only be enforced against the prosecution. ${ }^{120}$ But the adversarial process relies upon two sides to present the case, not one: "The very premise of our adversary system of criminal justice is that partisan advocacy on both sides of a case will best promote the ultimate objective that the guilty be convicted and the innocent go free." ${ }^{.121}$ The system certainly will not work well if we prevent prosecutors from addressing what is often the central issue in the case while defense lawyers would be free to confront it directly.

The Pabst rule is also hard to apply because trial judges are expected to figure out all of its permutations on the fly. Pabst told us that the trial judge has an independent duty to step in to prevent improper closing

118. E.g., Atkinson, 80 P.3d at 1150-52 (restriction on complaining witness in sexual-assault case regarding sex with defendant the day before alleged rape, which could have explained DNA evidence, and inconsistent statement of complaining witness about her relationship to defendant violated defendant's right to confront witnesses and to fair trial); State v. Jackson, 177 P.3d 419, 424-26 (Kan. Ct. App. 2008) (restriction on cross-examination of complaining witness in sexualassault case regarding key inconsistent statement and other abuse that might have caused emotional damage cited in testimony violated defendant's right to confront opposing witnesses).

119. See State v. Frost, 161 P.3d 361 (Wash. 2007) (defendant's right to fair trial was violated when trial judge precluded comment in closing argument that the state had failed to prove accomplice liability); Williams v. State, 912 So. 2d 66, 68 (Fla. Dist. Ct. App. 2005) ("No area is more deserving of 'wide latitude' [for argument] that the defendant's ability in a criminal case to argue the "credibility and biases of the witnesses who testified at trial."').

120. Although the Kansas Court of Appeals ruled in State v. Johnson that the Pabst rule applies with equal force to defense counsel, 86 P.3d 551, the defendant in that case did not argue on appeal that such a rule would violate the defendant's constitutional right to counsel or to a fair trial. Brief for the Appellee, State v. Johnson, 86 P.3d 551 (Kan. Ct. App. 2004) (No. 89,477). That's not surprising since the defendant actually had no real stake in the appeal. He had already been acquitted, and the appeal proceeded on a question reserved by the State.

121. Herring v. New York, 422 U.S. 853, 862 (1975). 
argument by the prosecutor. ${ }^{122}$ But the line has not been as clearly drawn in practice as Pabst might have suggested. For example, cases have not always resulted in reversals in which the prosecutor referenced lying only a time or two. ${ }^{123}$

In the 2007 case of State v. Miller,${ }^{124}$ the Kansas Supreme Court found prosecutorial misconduct when the prosecutor recited the acts that the State claimed the defendant had done in committing the murder of his wife because six times the prosecutor began a sentence with "the killer." 125 For example, the prosecutor said, "The killer walks on down the hall." Somehow, this too was the impermissible expression of personal opinion by the prosecutor, ${ }^{126}$ a conclusion that does not seem self-evident to me. If the evidence showed him to have committed the murder, it seems a fair statement to say that he was the killer. The prosecutor's case was that the defendant had gotten out of bed that night and then had killed his wife after he first made sure she was asleep. The first reference to a killer was, "We know at the very least when he stuck his foot outside of that bed, he took the first steps of a killer."127 Then the prosecutor made six further references to "the killer" with respect to movements the prosecutor contended the defendant had made as he prepared to kill his wife. ${ }^{128}$ Perhaps, as the court also concluded, these references to "the killer" were unduly inflammatory, but they seem to be a fair characterization of the inferences to be made from the evidence. After all, the court affirmed the first-degree murder conviction, ${ }^{129}$ ultimately finding that the prosecutorial misconduct in this case did not deny the defendant a fair trial. ${ }^{130}$

My experience as a trial judge for nearly fourteen years leads me to believe that the trial judge's task of policing Pabst violations in closing argument in the absence of objections is not one that can be handled without error. Saying that there can be no reference to a killer in closing

122. State v. Pabst, 996 P.2d 321, 326 (Kan. 2000).

123. State v. Finley, 42 P.3d 723, 730 (Kan. 2002) (finding that "the phrase 'they can't keep all the lies straight' does not come close to the egregious manner in which the prosecutor in Pabst called the defendant a liar"); State v. Wahweotten, 143 P.3d 58, 71-72 (Kan. Ct. App. 2006) (finding prosecutor's use of euphemisms for liar or lying not improper because "there were not repeated references to the defendant as a liar" and the comments were provoked by defense counsel's argument).

124. 163 P.3d 267 (Kan. 2007).

125. Id. at 292-95.

126. Id. at 293.

127. Id. at 291

128. Id. at 291-92.

129. Id. at 296.

130. Id. at 295 . 
argument in a murder trial—or even to "the killer" when recounting the events-certainly came as a surprise to me.

The inability to apply rules like this in a consistent manner was underscored less than a year after Miller. In State v. Scott, ${ }^{131}$ a capital murder case, the Kansas Supreme Court again considered several references by the prosecutor in argument to the defendant as "a killer" or "the killer." The court reviewed several of its previous cases in which a prosecutor had referred to a defendant as a "murderer" or "killer" and found a "consistent rule" - that "a prosecutor may refer to the defendant as a murderer or killer in the course of arguing that the defendant committed the murder" but may not do so to inflame the jury or when the comments don't relate to the evidence. ${ }^{132}$ If that "consistent rule" had been applied in Miller, surely the references to the movements "the killer" made in the house should have been considered fair comments based upon the evidence. But they weren't—and the Scott opinion does not cite to or discuss Miller.

Even without contradictory appellate decisions, it's sometimes hard for a trial judge to tell when to rein in attorneys during jury argument, especially since Kansas judges must control the argument without the need for any objection. ${ }^{133}$ Sometimes stepping in too soon interferes with the tactical choice an attorney may have made about which arguments to object to and which ones to use for his or her own purposes. I'm reminded of the tactical choice made by Humphrey Bogart's character in the 1949 film, Knock on Any Door, an example that also shows an improper use of the term "killer." Bogart was defending "Pretty Boy Romano," played by John Derek, for murder. When the prosecutor's opening statement called Romano a "jail-bird with a felony conviction," a "moocher to whom a police line-up is a weekly routine," an "outcast," the "king of the streets," and a "hoodlum killer," Bogart's character objected, but only to the phrase "hoodlum killer":

Object your Honor. I move the district attorney's remark be stricken from the record. As a matter of fact, all of his remarks are made to induce passion and prejudice. But I object only to hoodlum killer. In the case of a boy who's being railroaded, it's hardly an apt phrase.

131. 183 P.3d 801 (Kan. 2008)

132. Id. at 823 (citing State v. Scott, 21 P.3d 516 (Kan. 2001); State v. Hooker, 21 P.3d 964 (Kan. 2001); State v. Cravatt, 979 P.2d 679 (Kan. 1999); State v. Collier, 913 P.2d 597 (Kan. 1996)).

133. See State v. Fewell, 184 P.3d 903, 914 (Kan. 2008) (objection during trial not required to obtain appellate review of prosecutorial misconduct when right to fair trial is implicated); Pabst, 996 P.2d at 325 (same); State v. McCorkendale, 979 P.2d 1239, 1242 (Kan. 1999) (same). 
In movies, of course, everyone has a scriptwriter. The trial judge not only sustained the objection made, but also struck Bogart's reference to "a boy who's being railroaded." That's fiction, of course. In real life, it's difficult for the attorney to tell when to object and it's difficult for the trial judge to know either how to rule on objections or when to act even though no objection has been made.

\section{E. The Rationale for Pabst Criticized Here Was Not Necessary for the Pabst Result}

As noted above, the Pabst court could have reached the same result by relying only upon the first two authorities it cited, Lockhart and Mosley. ${ }^{134}$ The prosecutor in Pabst had allowed his closing argument to degenerate into the sort of name-calling affair properly criticized in Lockhart and had vouched for the credibility of his own witnesses contrary to Mosley and other cases. In addition, he had essentially shifted the burden of proof to Pabst by falsely claiming that Pabst had admitted that the jury should find him guilty if they concluded he had lied, followed by the argument that "[i]f you don't believe him, then he's guilty. And he admits it." When you consider all of that conduct together, the prosecutor's improper conduct was significant and supports the result in Pabst.

Prosecutorial misconduct is a real problem. Courts certainly must keep it from causing juries to convict the innocent; I do not suggest that there are easy answers to that problem. But we need not stretch a provision governing lawyer ethics well beyond its words to do so. ${ }^{135}$

\section{CONCLUSION}

Witness credibility is a key issue in most trials. Jurors deserve the full benefit of good advocacy for our adversarial system of justice to succeed. Attorneys should be allowed to address reasonable inferences about witness credibility based upon the evidence presented, along with all of the other issues in the case. Pabst's contrary teaching should be rejected-and a very recent case may indicate a move in that direction.

134. See supra notes $23-30$ and 42-45 and accompanying text.

135. A full discussion of prosecutorial misconduct is well beyond the scope of this Article. There are at least two treatises devoted exclusively to the law of prosecutorial misconduct. See Bennett L. Gershman, Prosecutorial Misconduct (2d ed. 2007); Joseph L. Lawless, PROSECUTORIAL MisconduCT (3d ed. 2003). 
In July 2008, in State v. Scaife, ${ }^{136}$ the court said that a prosecutor should be allowed to "explain[] to the jury what it should look for in assessing witness credibility, especially when the defense has attacked the credibility of the State's witnesses." 137 For the reasons discussed in this Article, however, a prosecutor's ability to make arguments about credibility should not be limited to cases in which the defense has launched its own credibility attack.

Before ending this criticism of Pabst, I would like to make a couple of personal comments. After all, this closing argument is not subject to the rules applicable to trials in Kansas. First, the views I have expressed in this Article are my own personal views, not the views of a judge deciding a specific case. I am a member of the Kansas Court of Appeals, an intermediate appellate court. Clearly, my court is bound to follow the precedents of the Kansas Supreme Court, and I will do so. Second, I note that the author of the Pabst opinion, now-retired Justice Fred N. Six, once requested thoughtful criticism of the court's opinions on the pages of this very law review. ${ }^{138}$ I have great respect for Justice Six and the other present and former members of the Kansas Supreme Court. We all miss the boat from time to time, ${ }^{139}$ however, and I hope that this article may convince its readers that the Pabst case was one of those times.

I have criticized the Pabst opinion in a series of annual legal-ethics seminars each year since the decision was announced. When the editors of the Kansas Law Review invited me to contribute to this Kansas issue, I felt that it was time to take Justice Six's invitation and set out in print my criticisms of Pabst. I leave it to the reader to decide whether my case was convincing.

\footnotetext{
136. 186 P.3d 755 (Kan. 2008).

137. Id. at 763

138. Fred N. Six, A Request for Thoughtful Criticism, 41 KAN. L. REV. 655 (1993).
}

139. For one of my misses as a district judge, consider the case of Owen Lumber v. Chartrand. I was initially reversed by a unanimous panel of the Kansas Court of Appeals, which concluded that I had misinterpreted a statute. 998 P.2d 509 (Kan. Ct. App. 2000). When the Kansas Supreme Court granted review, I assumed that some member of that court agreed with me, but that court soon added its own unanimous ruling that my interpretation had been wrong. 14 P.3d 395 (Kan. 2000). My ruling on remand gave effect to a statutory amendment intended to impact the case, but the Kansas Supreme Court unanimously concluded that doing so violated due process rights and reversed again. 73 P.3d 753 (Kan. 2003). On the second remand, I finally reached the merits of the case and was affirmed, 157 P.3d 1109 (Kan. 2007), though even then the Kansas Supreme Court did not agree with all of my legal conclusions. Id. at 1115 . I can assure you that I tried to get it right at each stage. But it's also clear that having someone else take a second look often can be helpful. 